\title{
Evaluation of Some Vegetable Wastes as Feedstuff for Ruminants
}

\author{
Ishraga Ezeldin ${ }^{1}$ Omer Massaad Elbashier $^{2}$, Shadia Abdelati Omer ${ }^{3}$ \\ 1, 2, 3 Sudan University of Science and Technology, Khartoum West, Khartoum, Sudan
}

\begin{abstract}
This study was carried out to evaluate the potentiality of the waste of beet (Beta vulgaris) leaves, carrot (Daucus carota), leaves and onion (Allium cepa) peel as ruminant feed through chemical composition, estimation of the in sacco study of the dry matter degradability (DMD), and effective dry matter degradability. Using in situ technique. The DM degradation characteristics were done by incubation the sample at $(0,3,6,12,24,48,72$ and $96 \mathrm{~h})$ in the rumen. The degradation within characteristics varied significant between the wastes. The range of the characteristics was $18.60 \%$ in the onion peel to $70.01 \%$ in beet for the soluble fraction (a), $28.43 \%$ in beet to $79.09 \%$ in onion peel for insoluble fraction (b) and $0.04 \%$ in onion peel to $0.21 \%$ in carrot for degradation rate. The effective degradability (ED) for the studied samples was highest at $F(0.02)$ ranged from $71.80 \%$ in onion peel to $91.95 \%$ in carrot rumen out flow rate and lowest at (0.08) ranged from $45.52 \%$ in onion peel to $86.08 \%$ in carrot. For all the wastes major DMD was between $72-96$ incubation times. The results of the studied vegetable wastes showed a good potential as a ruminant feed.
\end{abstract}

Keywords: Rumen degradability, vegetable waste, nylon bag technique, dry matter degradability, insoluble fraction

\section{Introduction}

Most of the developing countries have been fighting to provide adequate feed to their livestock, because of inadequate production of conventional ingredients for livestock feeding. The inadequate quantities of concentrated feedstuffs they produce annually are competed for by humans and livestock. .So the scarcity of feed sources often imposes a major challenge in livestock production in these countries [1] The challenge can be alleviated by the use of unconventional feedstuffs in animal feeding depending on their nutrient content, availability and acceptability to animals; and provided it is economical compared to conventional feed ingredients. The potential of by-products in animal nutrition has long been identified. Organic waste from markets represents about $10-20 \%$ of the total waste of a city. A large proportion comes from the overproduction of vegetables, turning them into potential pollutant. The nutritional value found for vegetable waste from a marketplace, these products might be considered as a potential alternative for animal feeding .The use of fruitsvegetable wastes in animal nutrition has attracted the attention of many researchers, due to the fact that these waste are locally available [9],The biodegradable waste presents high water content (from $60 \%$ to $80 \%$ ) [10], while the dry matter is relatively low [8], rich in nitrogen free extract [10]. [8], reported that vegetable wastes contain $12 \%$ crude protein, $13 \%$ crude fibre, $8 \%$ ash and $2 \%$ ether extract. [14], reported dry matter, crude protein, and ash for beet as high as 93.5\%, 13.2\%, and 9.4\%, respectively. Beetroot (Beta vulgaris) is botanically classified as an herbaceous biennial from Chenopodiaceae family and has several varieties, beet roots are the most popular for human consumption, both cooked and raw as salad or juice. Beetroots are rich in valuable, active compounds such as carotenoids, glycine betaine, saponins, betacyanines, folates, betanin polyphenols and flavonoids [24], [13[ reported the chemical constituents of carrot as moisture (86\%), protein $(0.9 \%)$, fat $(0.2 \%)$, carbohydrate (10.6\%), crude fiber (1.2\%), total ash $(1.1 \%)$, Ca (80 mg/100 g), Fe (2.2 mg/100 g) and p (53 mg/100 g) whereas, the values reported by [24], for most of these parameters are different i.e. moisture (88.8\%), protein $(0.7 \%)$, fat $(0.5 \%)$, carbohydrate $(6 \%)$, total sugars $(5.6 \%)$, crude fiber (2.4\%), Ca (34 mg/100 g), Fe (0.4 mg/100 g), p (25 mg/100 g), Na (40 mg/100 g), K (240 mg/100 g), Mg (9 mg/100 g), Cu (0.02 mg/100 g), Zn (0.2 mg/100 g), carotenes $\quad(5.33 \mathrm{mg} / 100 \mathrm{~g}), \quad$ thiamine $\quad(0.04 \mathrm{mg} / 100 \mathrm{~g})$, riboflavin $(0.02 \mathrm{mg} / 100 \mathrm{~g})$, niacin $(0.2 \mathrm{mg} / 100 \mathrm{~g})$, vitamin C (4 mg/100 g) and energy value (126 kJ/100 g).

However, to find out the optimum processing and utilization of such residues as animal feed, the seasonal availability and nutritive value of these by-products should be identified. Therefore, vegetable wastes could serve as an excellent source of nutrients for ruminants and can economize the production of animals [27]. To the best of our knowledge is limited information available on the use of vegetable as animal feed, in the Sudan. So this study was carried out to assess the nutritive value of these waste and to recycle them as ruminants feed and to contribute to the hygiene of the markets.

\section{Materials and Methods}

The study was conducted at the Farm of College of Animal Production Science and Technology, Sudan University of Science and Technology, Kuku area.

\subsection{Collection of Sample}

All vegetable waste samples were collected from Khartoum North Central Fruits and Vegetable Market. They were chosen according to the availability of waste during the study period. The collection was performed during the evening after finishing sale of products. Vegetable waste samples were air dried.

\subsection{Chemical Analysis}

Dry matter (DM) content was determined by drying the samples at $105^{\circ} \mathrm{C}$ overnight and ash by igniting the samples in muffle furnace at $525^{\circ} \mathrm{C}$ for 8 hs and crude protein content 


\section{International Journal of Science and Research (IJSR) \\ ISSN (Online): 2319-7064 \\ Index Copernicus Value (2013): 6.14 | Impact Factor (2014): 5.611}

was measured by the Kjeldahl method [5]. Ether extracts (EE) were determined by the method of [5] Crude fiber (CF) was determined according to the method of [24]. When crude protein, fat, water, ash, and fiber are added and the sum is subtracted from 100, the difference is NFE = DM(\%Moisture + \%CF + \%CP + \% EE + \%Ash).

\subsection{Experimental Animals}

Three animals of a local breed (Kenana) aged 4-5 and were fitted with rumen cannula as described by Brown, (1968); for the in situ study techniques. They were fed a balanced ration of concentrate and roughages to maintenance level with free access to water and salt lick.

\subsection{In Situ Study Technique}

The nylon bag technique of [20] was employed to measure the DM degradation characteristics of vegetable waste. Samples were milled in a hammer mill through a $3 \mathrm{~mm}$ sieve and subjected to standard rumen degradability procedures using three castrated calves of approximately $300-350 \mathrm{~kg}$ live weight. Nylon bags with $35-40$ J.1 $\mu$ pore size containing $5 \mathrm{~g}$ samples in duplicate were incubated in each animal for each of the incubation periods:3, 6, 12, 24, 48, 72 and 96 hours. The bags were removed, after incubation in the rumen, then washed with cold running water until the washing water ran clear and colorless. Zero time samples were not incubated in the rumen, but were washed with running cold water as above to determine their solubility at time $0 \mathrm{~h}$. The bags were oven dried at $72^{\circ} \mathrm{C}$ for $24 \mathrm{~h}$, then taken out, cooled in a dissector and weighted by sensitive balance. Dry matter disappearance (\%) was calculated as follows:

Weight of sample incubated- Weight of residue after incubation $\times 100$

Weight of sample incubated

The DM degradation data were fitted to the exponential equation (Qrskov and McDonald, 1979):

$$
\mathrm{p}=\mathrm{a}+\mathrm{b}\left(\mathrm{I}-\mathrm{e}^{-\mathrm{Ct}}\right)
$$

$\mathrm{P}=$ the disappearance of nutrient during time $\mathrm{t}$.

$\mathrm{a}=$ the soluble nutrient fraction which is rapidly washed out of the bags and is assumed to be completely degradable. $\mathrm{b}=$ the proportion of insoluble nutrient, which is potentially degradable by microorganisms.

$\mathrm{c}=$ the degradation rate of fraction $\mathrm{b}$ per hour

\subsection{Statistical Analysis}

The obtained data were subjected to one way (ANOVA) analysis of variance to determine the variation among the studied wastes with regard to DM degradability, degradation kinetics. Significant differences among the samples were assessed using least significant differences (LSD) test according to [12]. The Statistical Package for Social Sciences Program (SPSS), version (10) was used for the analysis.

\section{Results}

\section{Chemical Composition}

Table (1) shows the chemical composition of the vegetable samples waste. The CP content ranged from $7.04 \%$ in carrot to $16.28 \%$ in beet. The CF ranged from $7.80 \%$ in carrot leaves to16.00\% in beet leaves.

Table 1: Chemical Composition \% of the Studied Vegetable Waste:

\begin{tabular}{|l|c|c|c|c|c|c|}
\hline Components & DM\% & CP\% & EE\% & CF\% & Ash\% & NFE\% \\
\hline Samples & & & & & & \\
\hline Beet & 90.4 & 16.28 & 0.8 & 9.2 & 11.3 & 52.82 \\
\hline Beet leaves & 96 & 23.32 & 1.6 & 16 & 11.67 & 43.41 \\
\hline Carrot & 83.9 & 7.04 & 1.2 & 15.4 & 10.73 & 49.53 \\
\hline Carrot leaves & 95.5 & 9.35 & 2.8 & 7.8 & 21.16 & 54.39 \\
\hline Onion peel & 91.3 & 8.66 & 1 & 44.5 & 15.56 & 21.58 \\
\hline
\end{tabular}

DM: Dry matter

CF: Crude fiber

EE: Ether extract

(OMD): Organic matter digestibility

NFE: Nitrogen Free Extract

ME: Metabolisable energy

CP: Crude protein

(IVDMD): In vitro dry matter digestibility.

Table 2: Values for in vitro gas Production (mL/200 mg DM)

Times for the Studied Vegetable Waste:

\begin{tabular}{|c|c|c|c|c|c|c|}
\hline Samples & $\begin{array}{c}\text { Beet } \\
(\mathrm{M} \pm \mathrm{SD})\end{array}$ & $\begin{array}{c}\text { Beet leaves } \\
(\mathrm{M} \pm \mathrm{SD})\end{array}$ & $\begin{array}{c}\text { carrot } \\
(\mathrm{M} \pm \mathrm{SD})\end{array}$ & $\begin{array}{c}\text { Carrot leaves } \\
(\mathrm{M} \pm \mathrm{SD})\end{array}$ & $\begin{array}{c}\text { Onion peel } \\
(\mathrm{M} \pm \mathrm{SD})\end{array}$ & $\begin{array}{c}\text { Significance } \\
\text { Level }\end{array}$ \\
\hline $\mathrm{a}$ & $70.01 \pm 0.20^{\mathrm{a}}$ & $50.47 \pm 0.45^{\mathrm{c}}$ & $63.42 \pm 0.42^{\mathrm{b}}$ & $44.30 \pm 0.42^{\mathrm{d}}$ & $18.60 \pm 0.75^{\mathrm{e}}$ & $* *$ \\
\hline $\mathrm{b}$ & $28.43 \pm 0.37^{\mathrm{e}}$ & $43.40 \pm 0.57^{\mathrm{c}}$ & $31.25 \pm 0.47^{\mathrm{d}}$ & $46.82 \pm 0.42^{\mathrm{b}}$ & $79.09 \pm 0.93^{\mathrm{a}}$ & $* *$ \\
\hline $\mathrm{c}$ & $0.05 \pm 0.00^{\mathrm{b}}$ & $0.05 \pm 0.01^{\mathrm{b}}$ & $0.21 \pm 0.01^{\mathrm{a}}$ & $0.05 \pm 0.00^{\mathrm{b}}$ & $0.04 \pm 0.00^{\mathrm{c}}$ & $* *$ \\
\hline $\mathrm{a}+\mathrm{b}$ & $98.44 \pm 0.45^{\mathrm{a}}$ & $93.88 \pm 0.70^{\mathrm{d}}$ & $94.67 \pm 016^{\mathrm{c}}$ & $91.13 \pm 0.17^{\mathrm{e}}$ & $97.70 \pm 097^{\mathrm{b}}$ & $* *$ \\
\hline ED at F $(0.02)$ & $90.28 \pm 0.20^{\mathrm{a}}$ & $81.49 \pm 0.39^{\mathrm{b}}$ & $91.95 \pm 0.07^{\mathrm{a}}$ & $79.54 \pm 3.70^{\mathrm{b}}$ & $71.80 \pm 0.39^{\mathrm{c}}$ & $* *$ \\
\hline ED at F $(0.05)$ & $84.17 \pm 0.16^{\mathrm{b}}$ & $72.19 .88 \pm 0.30^{\mathrm{c}}$ & $88.68 \pm 0.09^{\mathrm{a}}$ & $68.08 \pm 0.18^{\mathrm{d}}$ & $54.42 \pm 0.53^{\mathrm{e}}$ & $* *$ \\
\hline ED at F $(0.08)$ & $80.89 \pm 0.16$ & $67.19 \pm 0.30^{\mathrm{c}}$ & $86.08 \pm 0.15^{\mathrm{a}}$ & $62.66 \pm 0.22^{\mathrm{d}}$ & $45.52 \pm 0.41^{\mathrm{e}}$ & $* *$ \\
\hline
\end{tabular}

$\mathrm{M} \pm \mathrm{S}$ : (Mean \pm standard deviation)

*significantly $(\mathrm{P}<0.05), * *$ : highly significantly different $\quad(\mathrm{p}<0.01)$

a,b,c,d,e: Means within the same raw followed by different

superscripts are.

a: soluble fraction (wash loss ).

b: degradation of the water insoluble fraction

c: degradation rate

$\mathrm{a}+\mathrm{b}$ : Potential degradability.

ED: effective degradability at rumen outflow $(0.02,0.05$, And 0.08$) \mathrm{F}$ : flow rate 


\section{International Journal of Science and Research (IJSR) \\ ISSN (Online): 2319-7064 \\ Index Copernicus Value (2013): 6.14 | Impact Factor (2014): 5.611}

Table (2) shows the dry matter degradation kinetics of the vegetable wastes. Beet showed the highest value for a fraction and potential degradability while the carrot showed the highest value for c fractions as well as the effective degradability at all the ruminal outflow rates, while the onion peel exhibited the highest for $b$ fraction which is subjected to degradation for the studied vegetable waste:

\section{Discussion}

There are many factors affecting chemical composition and mineral content of feed stuffs such as stage of growth, maturity, species or variety, drying method, environment and soil type, [26], [4] and [19]. These factors may partially explain differences in the chemical composition among the studied waste products.

Differences in the dry matter DM content of the samples could be attributed to the differing DM content of beet, beet leaves, carrots, carrot leaves and onion peel. The dry matter DM content in beet, beet leaves, carrot leaves and onion peel were comparable with the results reported by [23] and [19].

The crude protein CP content in beet leaves was similar to that published by [22]. The beet CP content was higher than the results by [11]. The CP content in carrot was higher than that reported by [23]. The crude protein content in onion peel was lower than that reported by [22]. The CP content in carrot, onion peel and carrot leaves were relatively close to that reported by [17], [11], [29], and [22] and highest than that reported by [14]

Ether extract (EE) is also known as crude fat which comprises of all substances that are soluble in ether. Although EE contain lipids, which provide energy it will also include other fat-soluble substances such as chlorophyll and fat-soluble vitamins. [5]. The ether extract ( EE) content in carrot leaves in this study is comparable with the result obtained by [23] and [3].The EE content in onion peel, beet and carrot were relatively close to that reported by [22], [17]. [23] and [14].

The nitrogen free extract NFE content in carrot leaves, and beet in this study were close with the results reported by [7].The NFE content in carrot and beet leaves were in agreement with that reported by [14]. The nitrogen free extract NFE content, represents the highly digestible carbohydrates indicated that they had the highest soluble cell contents. [25].

The crude fiber CF in beet in this study is comparable with the findings reported by [16] and disagree with which reported by Stanton and [24]. The CF in onion peel is close with that reported by [15]. The CF content results in carrot and beet leaves were lower than the reported by [16]. The crude fiber CF content is usually taken as a negative index of feed quality [25]. These include feed resources derived from crops grown for renewable energy such as sugarcane byproducts and root crops. Examples of this category would be waste material arising from the fruit processing i (citrus pulp waste) and root crops [2].
The ash content in carrot leaves is comparable with that reported by [29].The ash content in beet, beet leaves, carrot and onion peel were close with the results reported by [7]. The carrot exhibited the highest degradability rate; and this is most probably due to the high solubility of its content, which is inferred from the washing loss at the zero time [29]. Although the carrot leaves and the beet leaves have less crude fiber content than the onion peel but its degradability rate was lower than that of the onion peel. This can be attributed to the difference in the cell wall contents which are most probably got lignified, and lignin is known to resist the microbial breakdown of the cell wall [16].the beet exhibited the highest Potential degradability than the carrot due to the high solubility of its content, this is inferred from the (a) value, which is washed out quickly resulting in fast degradability rate.

It is summed from this study that vegetable wastes have a potentiality as ruminants' feed supplement; further work should be done to study their digestibility.

\section{Conclusion}

It was concluded that carrots, carrots leaves, beets, beets' leaves and onion peel have a good potentiality as source of nutrients for ruminants and can economize the production of animals.

\section{Recommendations}

Investigation of the presence of anti-nutritional factors and heavy metals on the vegetables waste should be done.

\section{References}

[1] Aregheore, E. M., Chemical composition and nutritive value of some tropical by-product feedstuffs for small ruminants - in vivo and in vitro digestibility. Anim. Feed Sci. Technol., 85 (1-2): 99,2000.

[2] AFRA; FAO and IAEA (International Atomic Energy Agency), : Development and field evaluation of animal feed supplementation packages. Proceedings of the final review meeting of an, 2000.

[3] AFZ: Association Française de Zootechnie. io - La Banque de données de l'Alimentation Animale French feed database. http://www.feedbase.com .Technol. 94: 15-27, 2011.

[4] Agbagla-Dolmini A.; Noziere, P; Clement, G. and Doreau, M. : In sacco degradability chemical and morphological composition of 15 varieties of European rice straw. Anim. Feed Sci. and .Technol. 94: 1527,2001.

[5] AOAC. Official Methods of Chemical Analysis. Association of Official Agricultural Chemists. Washington, DC. (16 ${ }^{\text {th }}$ edition), 1990.

[6] Brown G.F. Armestrong; D.G. and Macrae, J.C. : The establishment of one operation of cannula into rumen and re-entrant cannula into duodenum and ileum of the sheep. Vet., 124: 7881, 1968.

[7] Elkhidir et al.): Molasses blocks containing oil seed cake and/or urea versusa concentrate supplement in a basal 


\section{International Journal of Science and Research (IJSR) \\ ISSN (Online): 2319-7064 \\ Index Copernicus Value (2013): 6.14 | Impact Factor (2014): 5.611}

hay diet for feeding Sudan Desert Lambs. Sudan Journal of Animal Production, 2: 79-87. 1989

[8] Esteban, M.B.; García, A.J.; Ramos, P. and Ma'rquez M.C. Evaluation of fruit-vegetable and fish wastes as alternative feedstuffs in pig diets. Elsevier Science Direct.27: PP 193-200, 2007.

[9] FAO (Food and Agriculture Organization of the United Nations) Root and Tuber Crops, Plantains and Bananas in Developing Countries. No. 87, 1988.

[10] Garcia A. J; Esteban M.B; Marquez M.C, Ramos PBiodegradable municipal solid waste: characterization and potential use as animal feedstuffs.Waste Manag 25:780-7, 2005.

[11] Greg Lardy and Vern Anderson. Alternative Feeds for Ruminants. AS 1182 North Dakot (NDSU) State University, Fargo, North Dakota 58105. PP 6-23, 2003:

[12] Gomez, K.A. and A.A. Gomez, (1984). Statistical procedures for agricultural research (2 ed.). John Wiley and sons, New York, 680p, 1984..

[13] Gopalan, C. Sartri, B. V. R. and Balasubramanaian, S. C. Nutritive value of Indian Foods National Institute of Nutrition.Hyderabad, India, 2001.

[14] Holland, B., Unwin, I.D., Buss, D.H. Vegetables, herbs and spices. Fifth supplement to McCance and Widdowson's The composition of foods. Cambridge, UK: Royal Society of Chemistry, 1991.

[15] Ibrahim R.M. Eslami; Fayazi, J. and Jahromi, M.F. Effect of feeding steam treated pith bagasse on body change weight, milk constituents and blood parameters of lori ewes in khouzestan province, iran. Asian - Paki J. Nutrition 8: 1915-1919, 2009.

[16] McDonald P.; awards, R.A.; Greenhalgh, J.P.D. and Morgan, CA. (): Animal nutrition 6th Ed. p255 Pub.Pearson Education England, 2002.

[17] National Research Council (NCR) - National Academy of Sciences. : Nutrient requirements of beef cattle. 6th ed. NAS-NRC, Washington, DC. of discarded beetroot and potato hash silage on growth performance and digestibility in South African Dorper lambs. J.of.Anim. and V.A dvances 9: 853-856, 1984.

[18] Patil S. N.; Netke, S. P. and Dabadghao, A. K.,: Processing and feeding value of mango seed kernel for starting chicks. Brit. Poult. Sci., 23: 185-194, 1982.

[19] Promkot C. and Wanapat, M. Ruminal degradation and intestinal digestion of crude protein of tropical resources using nylon bag and three-step in vitro procedure in dairy Cattle. In : Proceedings of the Agricultural Seminar, Animal Science/Animal Husbandry. Held at Sofitel Raja Orchid Hotel 27-28 2004

[20] Ørskov E. R. and McDonald, I. : The estimation of protein degradability in the rumen from , 1979.

[21] Stanton.L. and LeValley1 S.B. (: Feed Composition for Cattle and Sheep Colorado State University, U.S. A:

[22] Suleman Y.R. and Mabrouk, A.A. The nutrient composition of Sudanese feeds. Bulletin III. Central Animal Nutrition Research Laboratory, Kuku Khartoum North.1999.

[23] Tobias Marino .C; Hector.B; Mazza Rodrigues P.H; Oliveira Borgatti .L. M; MarquesMeyer. P;Alves da Silva E.J.and Ørskov E. R Characterization of vegetables and fruits potential as ruminantfeed by in vitro gas production technique. Livestock Research for Rural Development 22:4-8, 2010.

[24] Vali, L., Stefanovits-Banyai, E., Szentmihalyi, K., Febel, H., Sardi, E., Lugasi, A., Kocsis,I.,Blazovics, A., " Liver-protecting effects of table beet (Beta vulgaris var. Rubra) during ischemia-reperfusion," Nutrition 23, pp. 172-178, 2007.

[25] Van Soset P. J. : Nutritional Ecology of the Ruminant. Part III. Chemistry of forages and feeds. O \& Books, Inc. Corvallis, Oregon. USA. pp. 76-78, 1982.

[26] Von Keyserligk M.A.G.; Swift, M.L.; Puchala, R. and Shelford, V. Degradability Characteristics of dry matter and crude protein of forages in ruminants. Anim. Feed Sci. and Technol. 291-311, 1996.

[27] Wadhwa M; Kaushal. S.Band askshi, M.P.S (): Nutritive evaluation of vegetable wastes as complete feed for goat bucks. Small Ruminant Research. vol.64:pp.279-284, 2006.

[28] Wadhwa M. BakshiM. P. S. Harinder and P.S. Makka. Utilization of fruit and vegetable wastes as livestock feed and as substrates for generation of other valueadded products. Food and Agriculture Organization of the United Nations (FAO), 2013.

[29] Wallet J. C: By-products and unusual feedstuffs. Feedstuffs Reference Issue and Buyer's 2006

\section{Author Profile}

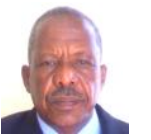

Omer Massaad Elbashier received the B.S. M.Sc. and $\mathrm{PhD}$ degrees in animal production and nutrition from Sudan University of Science and Technology in 1975, 1997, and 2003 respectively. Since 1975 I work in Sudan University of Science and Technology, teaching animal nutrition and animal anatomy. During 1979-1981, I stayed in USA to study an associate diploma in animal health and nutrition. Now I am an associate professor, in June I will apply for professor degree. 